\title{
\begin{tabular}{ll}
\hline 著 \\
\hline
\end{tabular} \\ ロ腔內の渜酸性菌数と口腔内現症との関係 \\ 戶州正雄 \\ 東京医科曾科大学微生物学教室（指導 清水教授）
}

\section{Numerical Responces of Aciduric Bacteria to Dental \\ States in the Mouth}

\author{
Masao Toganoh \\ Department of Microbiology, School of Dentistry, \\ Tokyo Medical and Dental University. (Prof. Shimizu)
}

\begin{abstract}
Number of aciduric bacteria in a oral specimen from 213 persons, classified into 15 healthy, 11 calculous, 7 gum inflamatory, 10 pyorrhoeal, 35 carious, 17 caries restored, 22 bridge wearing, 30 denture wearing and 66 miscellaneous in combination of above two or three categories, was counted by the method by Onisi and Kondo. According to the general acceptance, it was agreed that average of lactobacillus count in a group of the same number of carious teeth increased proportionally to the damage of tooth, but individual irregularity was too large to estimate the actual destruction of tooth as well as increasing destruction within certain period. In average number, countings from calculous and pyorrhoea patients were lesser than those from healthy mouths, and on the contrary countings from both carious and denture wearing mouth were significantly abundant. The hygienic state in a mouth seemed to have some effect to elimination of this organism. As the resulst, it was stressed that Lactobacilli opportunistically grow in a mouth, once a favorable enviroment is established there in some way, and its numerical increase does not respond to immunological state of dental caries.
\end{abstract}

\section{緒言}

唾液中の耐酸性菌の多宾々龄刢の発生並びに䶖 敛の進展の相関に就ては, Bunting \& Parmerl$\mathrm{ee}^{1)}$, Jay and Voorhees ${ }^{2)}$, H. T. Dean ${ }^{3)}$, 及び Rodoriguez ${ }^{4}$ 等に依り, 口腔内の齓刢の多いも のは耐酸性菌も多いと云うことが示されて以来, この現象に関する多数の研究が報告された。

Enright, Friesel, Triesel, Trescher ${ }^{5 l}$ は始め 脑䭒蝕を有する 19 例の内 9 例に Lactobacillus を
検出し, 其後 3 乃至 9 カ月を経てその 9 例中 5 例 に漓刢の拡大, 増加を認めたのに対し, 菌の検出 されなかつた6例の何れに於ても漓刢の進展を認

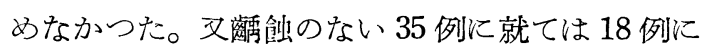
Lactobacillus を検出し，その内 13 例に蘺刢の発 現を認めたのに反し，同菌が検出されなかつた例 では殆んど鹖創の発現を認めなかつたと報告して 居る。

この実験成績に依つて, 唾液の一定量中に含ま れる耐酸性菌の菌数を测定し，その多寡に依つて 
撂刢の活働度を予期する可能性が強調された。

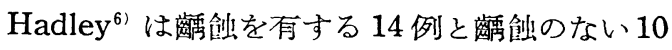
例に就て唾液中の耐酸性菌数の测定（以下 Lcount と略記す)を行い，唾液 $1 \mathrm{cc}$ 中に罹患者は 平均 60,000 , 非罹患者は平均 600 で著しい墓があ つたと報告して居る。

$\mathrm{Kesel}^{7)}$ は Illinoi Dent. Univ. の歯科学生 50 人に就て 549 回の L-count と 2 年間の口腔診查 の結果から, 䝆刢のない者より䕬刢歯数の増すに つれて, L-count の值も増し, 又㵧刢のない者丈 は僅少な者でも L-count 值が高い場合には後に 漓刢の発現或は拡大増加を見たと要約した。そし て以上の様な条件に完全に一致した者が全体の68 $\%$,一部一致した者が $16 \%$ ，全然一致しなかつた

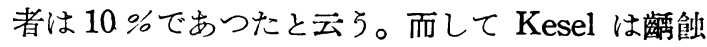

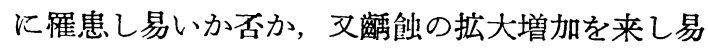
いか否かを譪刢活働度と称し, L-count 值の多少 に依つて活働度の高低を表し得ると述べた。

漓玲々耐酸性菌数の相関が平行して居るとする 多くの研究者の見解を綜合すると次の 2 項にな る。

1）臈蝕のない者又は僅少な者は L-count の值 も低く, 煐刢の数を増す程其の值が高くなる。即 ち L-count に依つて䒽刢に依る破壊の範囲を表 乙得る可能性がある。

2）更に䝆刢のない者又は僅少な者で L-count 值の高い場合には，後に踊刢の発現,乃至は拡大, 増加を来し易い。即ち L-count に依つて㵧玲増 加の将来をも予知せしめる可能性がある。

以上の結果から個人或は集団の L-count を行 らことは融刢予防を目的とする口腔衙生活働の重 要な基礎資料を与えることになる。Appleton ${ }^{8)}$ は 㵧伝の際の種々な相互作用を，一方に於て歯質を 崩壊する機構(D. Disintegrative Mechanisms) と 文反対にこの様な作用に抵抗する機構 (R. Resistance of enamel or dentin to the disintegrative mechanisms）とに分け， D/R が唃玲活㗢 度(A.=Activity) を表す值であると仮定して居 る。

即ち $\mathrm{D} / \mathrm{R}=\mathrm{A}$ とし
$\mathrm{D} / \mathrm{R}>1$ なる場合に羅患度が高いと云つて居る。 而してこの場合破壊機構の増大を Lactobacillus の数で表わせば活働度 (A)の増加を推定出来ると 説明して居る。

活働度 (A)の量的表現を目的として用いられた ものは Lactobacillus の数だけではなく、これに 代る種々の標準が多くの研究者に依つて提案され た。

即ち, 歯牙エナメル質粉末の唾液中での溶解量 の测定 (Fosdick $)^{9}$, 糖加唾液の酸産生能の試験 (Wach, Kesel ${ }^{10)}$, Snyder ${ }^{11)}$ ), 唾液中のアミノ酸 の定量 (Wach, Kesel ${ }^{12)}$ ), 等である。又霜牙及び 唾液の諸性状を単独で汉は幾つかの方法を組合せ て，活働性試験に役立たせようとする試みも多数 行われて来た。前述の $\mathrm{Kesel}^{7)}$ はエナメル質の唾 液中での脱灰試験, $\mathrm{pH}$ と滴定酸度とを験して, これらの方法と L-count とを平行して行つた方 が判定に容易な成績が得られると云つて居る。近 年に至り Rickels ${ }^{13)} は$ “ Saliva-Sucrose ” Mixture の 4 時間培養後の $\mathrm{pH}$, 総酸量 の测定, 及 び L-count を行い, この各々の試験と 1 年後の 臈蝕増加数との間の関係を見出し, 更にこの $3 つ$ の試験が互いに 推計学的に 有意の 関係にある 事 を認め, 殊に比色法に依る $\mathrm{pH}$ の测定值が最も 正確で臨床的にも簡便に実施出来ると報告した。 即ち “Saliva-Sucrose” Mixture 4 時間培盖後 の phを6.6〜6.2;5.8〜 5.4;5.0〜4.2;の 3 群( 各 Activity Low, Moderate, High) に分け

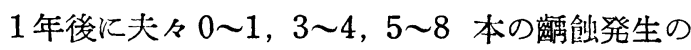
可能性があると結んで居る。

然しながら㵧蝕の Activity と L-count との 間の平行性に反対する実験結果もかなり存在す る。

即ち Johnson, Kaake, Agnew ${ }^{14)}$ は相当のLcount 值を有する览童に全然萾刢のない例を記載 乙, Johnson, William, et al $^{15)}$. Speidel, Boyd \& Drain ${ }^{16)}$ 等も L-count と萏刢の発現との間に 相関々係を見出せなかつたと云つて居る。

同様の結果が Boyd, Cheyne, Wessels ${ }^{17)}, \mathrm{R}$. Glass $^{18)}$ 等に依つて報告され推計学的な処理に依 
つて僃刢と L-count 值との平行性が否定されて 居る。

しかし Thompson ${ }^{19)}$ は L-count 值は唃刢の 岕場合には高いのが普通であるけれども，萭蝕

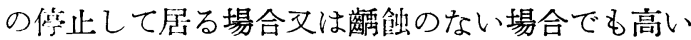
值を示す事もあることを指摘した。

これと同時に獦垥のない者から証明される Lactobacillus は䅎刢罹患者から分離される Lactobacillus より酸産生能の低い事に着目し，他の 何等かの因子が考えられねばならないと云つて居 る。

しかし Florestano ${ }^{20)}$ は抒刢䍜患者と非䍜患 者からの Lactobacillus に依つて産生される酸量 に相違を認めていない。

Tucker ${ }^{21)}$ は Lactobacillus が多数に居ると云 うより以外の要素が袖蝕の問題に関係して居るの ではないかと考光, Harison, Opal ${ }^{22)}$ も必ずし も䠛蝕を有する口腔から Lactobacillus が分離出 来る訳ではないので，他の因子が譪刢に関係する であろうと考㝋て居る。

この様な期待に反する実験結果に対して W. E. Clapper, R.A. Down, M.E. Heathermann ${ }^{23)}$ は L-count そ Caries Activity の相関を論ずる 場合に久けて居る因子として Lactobacillus の型 の相違に着目した。弗素を含む地域と含まない地 域の学音の唾液中の Lactobacillus の糖の分解能 及びガス発生能を検査し，併せて弗素のこの菌に 対する影響を検べ, Rhamnose を分解する菌が多

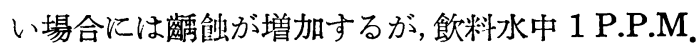
の弗素はこの菌に対し殆んど影響を与えないと云 う傾向を認めて居る。

菊窩が寧ろ耐酸性菌の発育に良好な環境を提供 して居ると云う考察は Boyd ${ }^{24)}$, Bibby ${ }^{25)}$ 等に依 つて行われたのであるが, Bleyney, Bradel, Ha$\mathrm{rtley}^{26)}$ の義歯床を有する口腔に耐酸性菌を増す と云う臨床的観察は耐酸性菌の発育増殖が莃窩の みによらない事を想像せしめる。

大西, 近藤 ${ }^{27)}$ はこの問題に関して人工床を口腔 内に装着する事に依り耐酸性菌数の増加を来し, はずすことに依つて再び元にもどる事を観察し,
耐酸性菌の多宾は漓刢活動度と無関係である事を 認め, 又との床の作る環境がこの菌の増加を来す のであろうと考察して居る。

以上の事実から考学ると耐酸性菌が䕬刢に依る 歯牙の破壊を代表するものであり，従つて耐酸性 菌の量が Caries Activity を示すと云う理論の 成立は相当困難な事情にあると考号られる。又耐 酸性菌数は床以外にも種々の口腔内の他の諸因子 に依つても増減を来すものである事も想像され る。

更に最近の薑刢の病理学的見解 ${ }^{28)}$ から見ても 䨑質の破壊を脱灰のみに帰することの不可能な事 が判り，従つて耐酸性菌のみに低つて滴刢変化を. 考える事は妥当ではない様に思われる。

即ち, 耐酸性菌の問題を㐨蝕以外の口腔内現症 とこの菌の量的関係に結びつけて考察し, 口腔内 の諸因子がこの菌の増減に如何なる影響を来すか， を知ることは Caries Activity と耐酸性菌の関 係を知る上に重要な資料となる 事が考えられる. ので，こ〉に本実験を行つた。

\section{実験方法}

\section{1. 実験対照}

専売公社東京地方局に勤務する 16〜64 歳の215 例に就て 882 回の L-count を行い, 臨床観察は 検查前 $3 \sim 8$ 年, 検査後 $1 \sim 1.5$ 年に涉つて精查し た。

\section{2. 口腔診査}

口腔診査は雬鏡及びェキスブローラーを用いて 注意深く行つた。診查時には咬合状態, 咬めるか 否か，清掃状態を観察し，檄刢に就てはその部位， 形態, 度数を, 又充继, 冠, 其の他補緅物に就て は，その部位，形態，使用材料，適合度を，其の 他歯牙の沈着物, 磨耗, 口腔内の疾病, 異状等に 就ては其の都度部位, 状態, 程度を記載した。

最初の診査後略ら半年毎に同様の観察を行い口 腔内の状態に就ての変化移動を記録した。

3. 資料採取, 培養, 及び菌数計算

口腔診查直後に資料の採取を行つた。即ち被検 者に予め連絡し冝食後㛜に含嗽, 飲食を禁じ, 食 
事 3 時間後の唾液を採取した。方法は先に大西， 近藤に依つて用いられた含嗽水を採る方法を用 いた。即ち，
Pepton
$\left.\begin{array}{l}0.15 \% \\ 1.0 \%\end{array}\right\}$
Glukose
$0.25 \%$

以上 $\mathrm{pH} 5.0$

の処方を有する Pepton 水 $8.0 \mathrm{cc}$ を以て 1 分間 口腔内を含嗽せしめた。

この際舌，煩，口答等を用いて特に㐘間空隙，

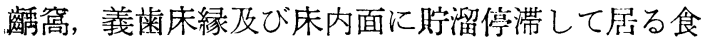
渣を充分に洗い出す様に訓練した。

使用培地は大西, 近藤 ${ }^{35)}$ に依つて考案された培 地を用いた。その処方は,

$\begin{array}{lc}\text { Yeastextrakt (Difco) } & 1.0 \% \\ \text { Pepton } & 1.0 \% \\ \text { Glukose } & 1.0 \% \\ \mathrm{NaCl} & 0.25 \% \\ \mathrm{Milk} & 100 \mathrm{cc} \\ \mathrm{NaN}_{3} & 1: 10000 \\ \text { Agar } & 3.0 \%\end{array}$

$0.2 \%$ C.P.R. ; $0.2 \%$ B.C.G. 各々 $5 \mathrm{cc}$ 以上 $\mathrm{pH} 6.0110^{\circ} \mathrm{C}, 15$ 分滅菌 Aq. dest $900 \mathrm{cc}$

採取した資料に 1 2 滴のカプリルアルコール を加兄て泡を消し，倚 $10 \mathrm{cc}$ になる茫前記処方の ペプトン水を増量する。

直ちにホールピペットを用いて用意した别の試 験管中のペプトン水で稀釈, 順次稀釈後, このぺ プトン水中に含まれる耐酸性菌の総数を計算す る。即ち最後の稀釈液中の $0.1 \mathrm{cc}$ をメスピペッ トを以て前記培地上に流し，コンラーヂ棒で平等 に展開塗布した後 Candle jar に納めた。

稀釉は 1 平板中に 100〜250の Colony の場合 が適当と考光られたので29)301，各例毎に予めその 稀釈倍数を测つて, 本試験ではその倍数を用いた。

培養は Candle jar を用いて $37^{\circ} \mathrm{C} 24 \sim 48$ 時間 行い，酎酸性菌の数を数えた。この培地に生える 耐酸性菌は毎常その Colony の周囲に黄色の暈を 生ずるので判然として居る。この方法で同一被検 者に対し 1 週間の間隔で 3 乃至 6 回資料を採取,
毎回直ちに培養検査を行つた。

\section{実 験結果}

215 例中 2 例に就ては 18 回测定したが毎回菌数 零であつた為(後述), この 2 例を除いた 213 例に 就て, 次の分類を試みた。

先づ口腔内の現症に依つて,

健全者(15例)

歯石沈着(11 例)

歯肉炎( 7 例)

歯槽膿漏(10 例)

唃欱放置 (35 例)

煐欱処置完了 (17 例)

床義歯 (30 例)

其の他

歯石沈着十歯肉炎 ( 6 例)

膿漏十処置十一部放置 (11 例)

一部放置十充填 $(28$ 例)

床十歯槽膿漏 $(12$ 例)

の 12 群に分類した。

次に同一個人の日に依る変動の性質を検べる必 要があつた。

そこで各例の平均值を $100 \%(\log .2)$ とし，同 一例の各実测值の平均值に対する百分率の対数を

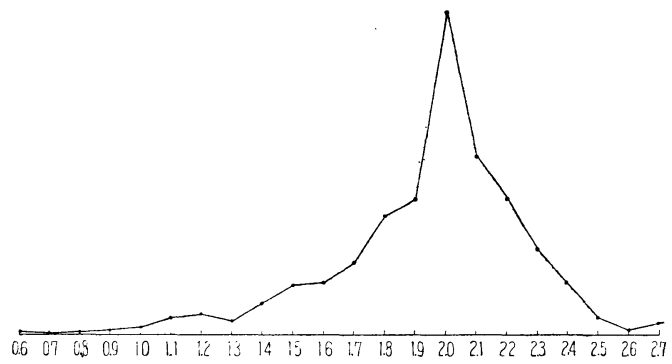

被検者 213 例, 864 回 (但, 2 例 0 のもの 18 回を除く)

図 1 耐酸性菌数計算値の対数分布 各個人の平均値を $100 \%(2.0)$ とした場合の各 回菌数平均值の \%対数分布

取り，その度数分布表(図 1)を作成し，この図か ら，この程度の短かい期間では個人の日に依る変 動が対数正規的であることを知つた。大西，近藤 の成績でも連続 2 週間の L-count 值は正規分布 して居るので，同一人に就て数日間测定して得た 值の算術平均值をその人の L-count 值として正 


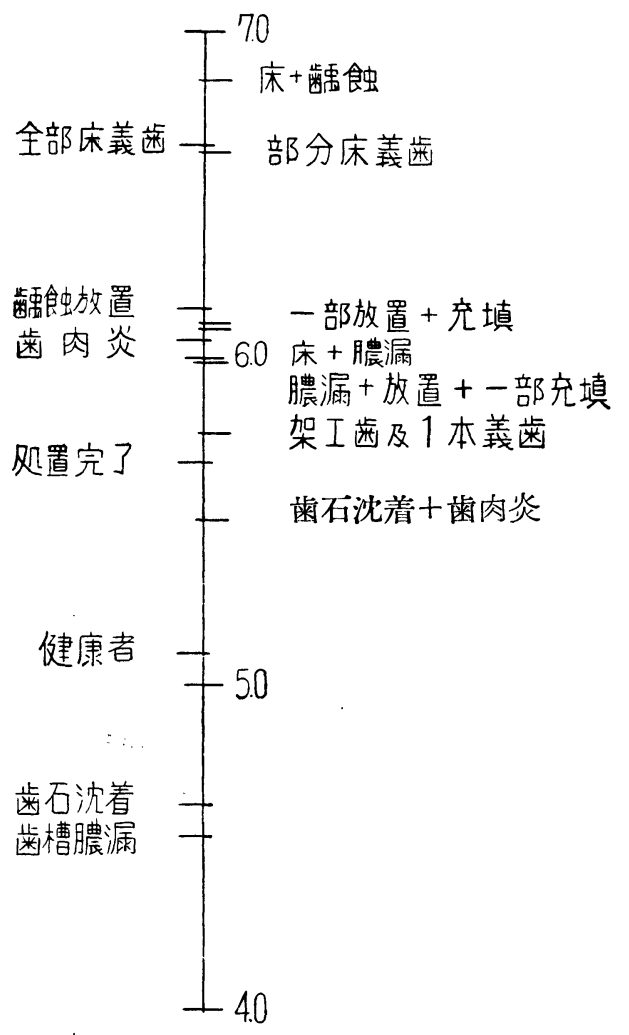

困 2 耐酸性菌数と口腔状態

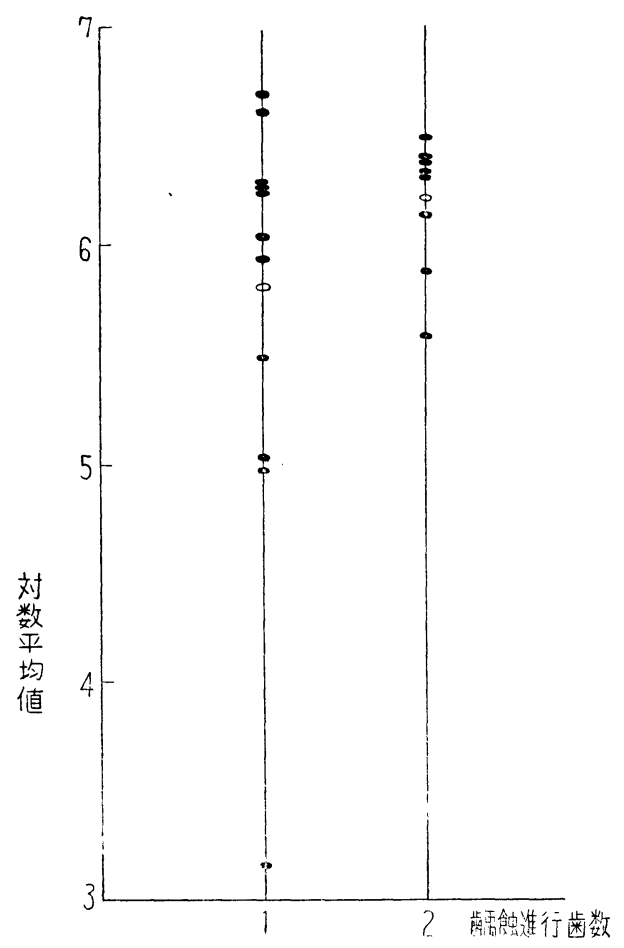

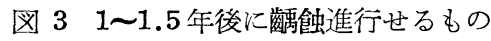

表 1 耐 酸 性 菌数と口腔状 態

\begin{tabular}{|c|c|c|c|c|c|c|c|c|c|c|c|c|}
\hline No. & 例数 & 項 目 & $\log \ddot{x}$ & $\mathrm{~T}$ & $\begin{array}{l}\text { 有意差 } \\
\text { 模定 }\end{array}$ & \multicolumn{2}{|c|}{ No. 例数 } & 項 & 目 & $\log \ddot{x}$ & $\mathrm{~T}$ & $\begin{array}{l}\text { 有意差 } \\
\text { 模 }\end{array}$ \\
\hline 1 & 15 & 健 全 者 & 5.095 & 3.187 & & & & & & & & \\
\hline 2 & 11 & 西 石 沫着 & 4.628 & 3.533 & - & & & & & & & \\
\hline 3 & 7 & 歯 & 059 & 0.511 & + & 9 & 6 & 㐘石沈竞 & +蹸肉炎 & 5.502 & 3.110 & - \\
\hline & & PN & & & & & & & & & & \\
\hline 4 & 10 & 画 槽 膿 漏 & 4.531 & 3.427 & - & 10 & 11 男 & 膿漏十放置. & +1 部処置 & 5.989 & 0.541 & + \\
\hline 5 & 35 & 隩虽 蝕 放 置 & 6.150 & 0.573 & + & 11 & 28 & 1 部 & + & 116 & 39 & + \\
\hline 6 & 17 & 処 置 完了 & 5.680 & 2.309 & - & & 20 & 1 - माP & & .210 & 0.007 & $T$ \\
\hline 7 & 22 & 架工困及び 1 本義 & 763 & 0.429 & + & & & & & & & \\
\hline & & $-\frac{1}{\sqrt{9}}$ & & & & 12 & 9 & 床十膿 & & 6.101 & 2.560 & - \\
\hline $8 \mathrm{a}$ & 4 & 床 義 歯(全部床) & 6.645 & 0.632 & + & 13 & 12 & 床十葪 & & 6.848 & 0.643 & + \\
\hline $8 \mathrm{~b}$ & 26 & $\mid$ 床 義 橉 (一部床) $\mid$ & 6.633 & 0.441 & + & & 1 & & & & & \\
\hline
\end{tabular}

註 : 有意差の检定は $5 \%$ の仜険率に於て健全者と他の項目との比較。十は有意差のあることを示す。

確を期することが出来た。

次に各分類項目毎に，その平均值，涼却限界，
及び健全者群と他の各群との有意筀の検定 ${ }^{311}$ を行 つた。 
最初実测平均值を以て直ちに上記の值をを計算 乙心処，標準偏学が異常に大きく，正規分布として 扱えないことが判り，対数正規分布として扱うこ そに依つて,かなりの精度で適合する事を知つた。

以下に示寸数学は対数正規分布として扱つて得 たものである。

即ち各群の平均值は,

健全者(5.095)を中心として

歯石沈着(4.628)及び

䨑槽膿漏(4.541)が之より低く,

床義歯(6.645 及び 6.633)を最高として

㽬玲放置(6.150), 歯肉炎(6.059), が之に次ぎ 齣蚛処置完了(5.680)

と次第に健全者群に近づく様な結果が得られた。 又之等の群の組合せと見られる他の各群も, 大体 その中間の值を示す結果であつた(表 1 及び図 2)。

こ〉に歯石沈着, 歯肉炎, 歯槽膿漏の三者の区 別であるが，臨床上歯牙の弛緩動摇，歯牙の移動 に依る咬合不整, 㕬耗, 歯根部の露出, 高度の茵 肉炎及び歯石沈着, 歯槽よりの排膿等, 明膫な症 状が幾つか見られるもののみを䨑槽膿漏とし，他 のものは主として，一つのみの症状が見られる 時，その分類の中に含めた。

又各群の率却限界は危険率 $5 \%$ で

霜石沈着 $( \pm 3.533)$

歯槽膿漏 $( \pm 3.427)$

健全者 $( \pm 3.187)$

唃蛤処置完了 $( \pm 2.309)$

一か異常に大きく,

床義歯 $( \pm 0.441)$

歯肉炎 $( \pm 0.511)$

煐刢放置 $( \pm 0.573)$

が小さかつた。

実却限界の大きいものは床義霜の場合を除いて

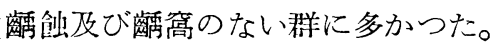

次に健全者群とそれ以外の各群との有意答の検 定を行つた結果は，表1に示寸通りであり，やは り穣却限界の大きいものとの間に於てのみ健全者 群との間に有意の楼が見られなかつた。次に㐨玲 .非罹患者と罹患者, 朔触数の少い者と多い者とを
比較すると，3 歯位迄は全平均值で 増加して行く 様な結果で，それ以上の煐刢雪数では，菌数との 間に平行性が見られなかつた。

又菌数計算後の口腔診查々鬻玲の増加との関係 は, 検査後の観察期間が $1 \sim 1.5$ 年で, 215 例中 22 例の皡刢増加者があり，図 3 に示寸様に全平均值 の上で僅かに平行性がある様な結果であつた。

\section{考按}

実験の結果，菊猞のない 1 例，有するもの 1 例 の 2 例に就て, 18 回検查したが常に耐酸性菌数零 のものが観察された。このことは Everyn, Tilden, $\mathrm{Svec}^{32)}$ \& 87 例中缷刢進行中にも拘らず菌 の検出を見なかつた 3 例を報告して碭る。Everyn 等は Bakterial Plaque 内の 耐酸性菌を問題 にし, Plaque 内部の菌が採取されない限りは判 定は困難であると云つて居るが, Plaque 内の Lcount と唾液の L-count は平行して居ると云う 実験報告がある ${ }^{33)}$ 。大西, 近藤, 加藤, 根本, 今 川 は24 Plaque を構成して居て歯牙の表面に着 生常在する菌は, Leptotrichia 或いは Jodococcus Vaginatus で Lactobaccillus を含む多くの口㻠 細菌は固有の Plaque より更にその表層に存在し て居ると考えて居る。

又実験に用いた含嗽用の Pepton 水は粘着性の 唾液を均等に稀喽せしめる作用を持つので，Plaque 表面の耐酸性菌はこの中に採取されて居る ものと推定してもよいであろう。

従つて上述の 2 例は Plaque 内にも耐酸性菌が 少いか，又は零に近いものであろう。鬼も角もこ の様に説明の困難な例のある事は事実である。

偖て，この実験で著しい事実は床義歯群と歯槽 膿漏群との L-count 值の甚しい差である。即ち 床義歯群が異常に 高い L-count 值を示し，歯槽 膿漏群が低いL-count 值を示した事である。床 に依つて耐酸性菌の増加する現象を大西, 近藤 ${ }^{35)}$ は実験的に再現し，その理由としてカタラーゼを 発生しない Lactobacillus が酸素の供給の悪い義 歯床の下で，殊にその部分には食物残渣が貯溜し 易いので，良い発有環境が得られるのであろうと 
考えて居る。即ち, 食後歯刷子で口腔清挦を行つ た值後の L-count 值と, 床義歯を装着した例, 床義歯内面にアセチール七ルローズを用いた例, 床義歯内面に葡萄糖とアセチール七ルローズを併 用した例の 3 時間後の L-count 值の増加率を测 定し, 夫々 $1.4,6.6,22.7$, の值を得て居る。又 床を数日間装着する事に依り 異常に L-count 值 が増し, 取りはずすと直ちに L-count 值が減少し て平常の值に復することを報告して居る。この事 から L-count 值を増加させる原因として局所の 環境が意外に大きな因子をなして居ると考えられ る。

全体的に見れば, 唾液中の耐酸性菌数は健全者 より菤玲のあるものの方が多く, 充填, 冠等の処 置に依つて減ずる事が認められる。即ち, 健全者 群と漓玲放置者群の間では明らかに有意の拻が認 められ，処置完了者群との間には有意の差が認め られず,一応 L-count 值を Caries の Index と し得ると云う説に一致した様に見えるが，各個人

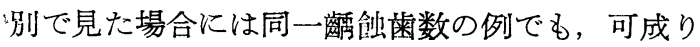
の変動が認められ，文瀜刢歯数と L-count 值が 逆になつて居る例もかなりあるので，この事から L-count 值を Caries の Index として用いる事 は不可能の様に考光られる。

向口腔診查時に行つた口腔清掃状態の検査に就 てては全洋を通じて，その対数平均值が

良 (5.703)

可 (5.908)，

不良 (6.875)

と云う順で夫々不潔になる程 L-count 值が増加 を示して居る。

清掃度に就ての標準が判然としないので相当主 観に左右されると思うが，毎回の診查表を照合す るとそれ程の移動が見られず，この点も参考とし て決定した結果であるので，口腔内の不潔なこと もこの菌の増加を起させる事が想像される。文歯 石沈着者群及び歯槽膿漏者群は健全者群と比較し て有意の共は認められなかつたが象も角 L-count 。の平均值は最低值を示して居る。

一方明らかに歯槽膿漏症の患者で床義歯を装着
して居る場合の L-count は可成り高い值を示し て居て(膿漏十床)群と(歯槽膿漏)の久の群との平 均值を比較すると $5 \%$ の危険率で明かに有意の筀 を認める事が出来る。この事実は, 口腔内の耐酸 性菌が局所の環境に依つて，可成り大きな影響を 受ける事を物語るものである。

\section{綜括}

1）成人 215 例に就て, 口腔内現症と唾液中の耐 酸性菌々数の関係に就て観察した。

2）歯石沈着，歯槽膿漏の者に酎酸性菌々数少 く，床義歯を装着する者は毎常多数の耐酸性菌を 有して局た。

3）集団的に見た場合健全者より藹刢を有する 者の方が耐酸性菌数が多かつた。しかし各個人に 就て見た場合には変動が甚しく，菌数から唃刢の 活動性を推定する事は不可能であると考えられ た。

4）口腔内の清掃状態も耐酸性菌の 多㙞に影響 する様に考えられる。

5）歯槽膿漏患者で 床義歯を装着して居る例と 装着して㞌ない例では耐酸性菌数に大きな前があ り, 推計学的にも有意の宏が認められた。

6）以上の諸点から考学て，唾液中の耐酸性菌 は口腔内の局芹の種々な要因から増減を来すもの であつて, 唾液中の耐酸性菌数のみに低つて, 直 ちに漓飿活動性の問題を結論づける事は不可能の 様に考えられる。

稿を終るに臨み終始御想篤な御指導と御棱閲を賜つた 恩師清水教授，大西助教授並びに本研究に種々の御援助 を頂いた近藤助手に深甚の謝意を表する。

\section{交 献}

1) Bunting, R.W., and Parmerlee, F.: The role of B. acidophilus in dental caries. J.A.D.A. $12: 381,1925$.

2) Jay, P. and Voorhees, R.S.: Bacillus acidophilus and dental caries, Dent. Cosmos $19: 977,1927$.

3) Dean, H. T.: Domestic water and dental caries. II. N. Federal Security Agency. 1927.

4) Radriz, F. E. : Method of determinating 
quantatively the incidence of $\mathrm{L}$. acidophilus odontolycus in the saliva. J.A.D.A. 17 : $1711,1930$.

5) Enright, I. J., Friesell, H. E., \& Trescher, M. O. : Studies of cause and nature of dental caries. J.D. Res. $12: 759,1932$.

6) Hadley, F. P.: A quantative method for estimating B. acidophilius in saliva. J. D. Res. 13 : 415, 1933.

7) Kesel, R.G.: Dental caries : etiology, control, and activity tests. J.A.D.A. $30: 25$, 1943.

8) Appleton, J. L. T. : Bacterial infection in dental practice. Lee \& Febiger Co. 4 Edition 453, 1950.

9) Fosdick, L.S. : The etiology and contorol of dental caries. J.A.D.A. 29 : 2132, 1942.

10) Wach, E.C., and Kesel, R. G., et al : Testing caries activity by acid production in saliva. J.D. Res. $22: 415,1944$.

Kesel,R.G.: Dental caries : etiology, control and activity tests. J.A. D. A. $30: 25$, 1943.

11) Snyder, M.L.: Correlation and comparison of laboratory findings with the clinical evidence of caries activity in a group of sixty-six children. J.A.D.A. 29 : 2001, 1942.

12) Wach, E. C., et al : Amino acids in human saliva. J. D. Res. 26 : 4, 1947.

13) Rickels, N. H. : The estimation of dentalcaries activity by a new colorimetric laboratory. J. D. Res. $32: 2,1953$.

14) 15,16 19, 21) 22) Moris, E. D.: The bacteriology of oral cavity. Brit. Dent. J. $11: 260,1953$. より引用.

17) Boyd, J, D., Cheyne, V. D. and Wessels,K. E. : Is the salivary lactobacillus count a valid index of dental caries Proc. Soc. Exp. Biol. \& Med. 71 : 535, 1949.

18) Glass, R.L.: The lack of relationship between salivary lactobacillus count and dental caries activity. Oral Surg. Oral Med. and Oral Path. 5 : 210, 1952.
20) Thompson, R.: aciduric organismus in dental caries. J. D. Res. $12: 759,1932$.

23) Clapper, W. E., Downs, R. A., and Healhermann, M.E.: The relation of caries activity lactobacillus counts and types and to the fluoride content counts and types and to the fluoride count of drinking water. J.D. Res. $32: 27,1953$.

24) Boyd, J., Zentmire, Z., and Drain, C.I. : Bacteriological studies in dental caries. J. D. Res., 13 : 432, 1933.

25) Bibby, B. G. : Neglected factors in the study of dental caries. J.A.D.A. $22: 222$, 1935.

26) Bleyney, J. R., Bradel, S. F., Hartley, G. F. : Caries activity as meassured by quantative estimation of oral lactobacilli. J. D. Res. $18: 260,1939$.

28）大西正男 : 人缡蝕の病因に関する細菌の研究. 界展望 $10,10: 29 ; 10,11: 33 ； 10,14: 29$, 1953.

29）大西正男, 加藤貞治 : 菌数計算の誤差に関する考 察, 日本細菌学雑誌 5(5) : 237, 1950.

30) Parmar, D., Kitchin, P., and Robinson, H. : Variation in count of Lactobacilli made from single specimens of saliva. J.D. Res., $25: 475,1949$.

31）高橋晄正, 土肥一郎：医学及び生物学研究者の ための推計学入門. 医学書院 : p. 17, 1951.

32) Everyn,B., Tilden $Z$., \& Svec, M.: Further studies of a defferential culture technique for estimations of acidogenic bakteria in saliva. J. D. Res. $31: 831,1952$.

33) Inverso, H.S., Green, G.E., \& Dodd, M.C. : Studies of the microflora of dental plaques after dispersion by ultrasound. J.D. Res. $34: 697,1955$.

34）大西正男, 近藤亘, 加藤貞治, 根本元, 今川与曹 : 所謂ヨードコックスの生態とその培養に就いて， 日本米科医師会学術会議会誌 $36: 1949$.

35) Onishi, M., Kondo, W.: Establishing an enviroment for growth of aciduric bacteria in the oral cavity. J.D. Res. 近刊. 